\title{
Two Tales of Civil Disobedience: A Reply to David Lefkowitz
}

\author{
Kimberley Brownlee ${ }^{1}$ (D)
}

Published online: 31 May 2018

(C) The Author(s) 2018

In his article 'In Defence of Penalizing (but not Punishing) Civil Disobedience', David Lefkowitz (2017) neatly maps out the differences between his and my defences of the moral right to civil disobedience. We disagree, first, about its grounds and, second, about its scope.

Concerning the grounds, I argue that the right to civil disobedience is grounded in people's rights to freedom of expression and conscientious action. By contrast, Lefkowitz, like Raz (1979) and others, argues that it is grounded in people's political participation rights, that is, broadly, their rights to have an equal say over lawmaking. Concerning the scope, I argue that the right to civil disobedience provides people with defeasible normative protection against all forms of state interference with their acts of civil disobedience including penalisation. By contrast, Lefkowitz argues that the right protects against punishment, but not against penalisation for civil disobedience. Let me take each disagreement in turn.

With respect to the grounds, Lefkowitz and I might try to call a truce and agree that, like many other rights, the right to civil disobedience is grounded in a plurality of values and interests. ${ }^{1}$ Both of our proffered grounds might be correct. However, attractive as a truce would be, our disagreement about the grounds is not just a matter of 'You say "potato", I say "potahto"'. Despite Lefkowitz's claims to the contrary, the political-participation ground that he offers does not yield a general moral right to civil disobedience for all members of a polity regardless of their political status. It yields a right only for people who are sufficiently politically disadvantaged.

\footnotetext{
${ }^{1}$ For a defence of pluralism, as opposed to foundationalism, with respect to human rights, see Tasioulas (2012). Tasioulas argues that a plurality of normative values and human interests ground human rights.
}

Kimberley Brownlee

K.Brownlee@warwick.ac.uk

1 University of Warwick, Coventry, UK 
Raz (1979)'s regime-specific version of the political-participation account has the same fault. It gives a moral right to civil disobedience only to people who live in an illiberal regime, are denied adequate participation rights, and must reclaim those rights from their regime through civil disobedience. In Raz's view, any participation-protected people living in that regime have no right to civil disobedience even if they wish to act in solidarity with the people who must reclaim their rights, because they have no participation rights that they themselves need to reclaim. Moreover, in Raz's view, no one living in a liberal regime has a moral right to civil disobedience for the same reason: by stipulation, they have no participation rights that they need to reclaim.

Lefkowitz's account is better, as it is not regime-specific. He argues that people living in a liberal regime can have a moral right to civil disobedience, but only when they wind up in the minority on a given issue and must work against the bad luck of having fewer resources and insufficient time to persuade people before decisions are made. To ensure that their right to have an equal say over law making is meaningful, they have a right to continue to champion their cause after decisions are made, through a variety of means including the comparatively expedient, publicitygrabbing measure of civil disobedience.

What Lefkowitz's account does not ground, but my conscientious-expression account does ground, however, is a moral right for someone who endorses the majority view to civilly disobey. Suppose a person defends the majority-endorsed current law in her society that women have a right to safe, timely, and accessible abortions at any stage of pregnancy regardless of the reason. Then, suppose this person sees a vocal, politically powerful, anti-abortion minority mounting an effective campaign that is prompting politicians to consider imposing strict limits on abortion access. In Lefkowitz's view, this pro-choice defender has no moral right to civil disobedience, I take it, since her view is both the law and the majority-held view. Moreover, in his view, the anti-abortion minority has no right either, I take it, since they are adequately well-resourced to make their case through conventional channels. In my account, both the pro-choice defender and the anti-abortion minority have a moral right to use civil disobedience to express their sincere and deeply held convictions, to seek to engage others in dialogue, and to aim to bring about lasting effects on the law.

If Lefkowitz wished to say that the pro-choice defender does have a right to civil disobedience, he would have to do some definitional acrobatics with the concept of a minority. Does being in the minority mean simply having fewer resources to defend one's view than one's political opponents have? (Defenders of the prevailing view or current law might have fewer resources than their opponents.) Does being in the minority mean holding a view that is not the law? (The majority of people might hold such a view.) Does it mean being outvoted or out-lobbied when politicians decide to make changes? (If politicians listen to a vocal, insistent, well-resourced numerical minority, the majority could be outvoted on a given issue.) Does it mean being directly negatively affected by a law? (The majority of people might be directly negatively affected. Moreover, people not negatively affected might want to support those who are.) Does it mean being among traditionally marginalized, disadvantaged groups whose opinions have less sway in public debates? (Such 
people may be the majority of people. They may also hold the majority view on a given issue.)

Conceptual niceties aside, by definition, some people do not hold minority views and, hence, have no moral right to use civil disobedience to defend those views in Lefkowitz's account, even though he maintains that the right 'is a right enjoyed by all members of the community'. ${ }^{2}$

One virtue of my conscientious-expression ground for the right to civil disobedience is that it applies the right generally, to defenders of majority and minority views alike: the right is not conditional on the content or the popularity of people's views. This account better aligns with an intuitively appealing understanding of civil disobedience, namely, that it is a suitably constrained, illegal method of political engagement that people do have a right to use when that is necessary for them to stand up for their deep convictions.

In pursuit of a truce about what grounds the right to civil disobedience, we could look for a different argument for the political-participation ground that does not turn on persons' relative political disadvantages. For instance, we could make an instrumental argument that civil disobedience has significant deliberative value in political decision-making, regardless of who resorts to using it. ${ }^{3}$

Let me turn now to the scope of the right to civil disobedience. Calling a truce about the grounds would not have to be costly for Lefkowitz when it comes to his account of the scope of the right. In order to entertain the idea that while the state may not punish people for exercising the right to civil disobedience, it may penalize them for doing so for instrumental and symbolic reasons, Lefkowitz does not need to show that political participation is the sole legitimate ground for the right to civil disobedience. He need show only that it is one legitimate ground for the right whose exercise must be regulated as part of a larger institutionalized system of democratic governance.

Of course, showing that political participation is one ground for the right does not show that penalizing civil disobedience is legitimate. I continue to maintain that it is not, for many reasons. Some of these reasons I have identified in past writing, ${ }^{4}$ and

\footnotetext{
${ }^{2}$ Lefkowitz (2017), 6. At most, Lefkowitz can say that these people have a conditional right, which could only become actual if their circumstances become sufficiently disadvantageous. Indeed, one could press harder and say that Lefkowitz does not unambiguously grant anyone a moral right to civil disobedience. Kartik Upadhyaya has observed to me that Lefkowitz's account limits such rights not merely to minoritymembers, but to those minority-members 'who may justifiably complain that, had there been further time for debate and deliberation, or had they enjoyed greater resources for the dissemination of their arguments, their own (reasonable) views might have won majority support' (p. 4, emphasis added). Whether this condition is often met is controversial, Upadhyaya argues. If the complaint Lefkowitz describes is interpreted literally, then, although it is almost always epistemically justifiable, it appears normatively unpersuasive. The possibility that a given minority-member's views would have been majoritarian is difficult to rule out, and therefore easy to justify. But the mere possibility of unfortunate disadvantage is a weak ground for complaint. If, however, the complaint is interpreted more persuasively, then it appears rarely to be epistemically justifiable. For instance, when there is not just a possibility, but also a good chance, that a minority-member's views would have been majoritarian, she seems to have stronger grounds to complain of unfortunate disadvantage. But, she is unlikely ever to be in a position to provide evidence for a counterfactual of this sort, even when it is true.

3 See Brownlee (2012), chs. 3 and 5; and Markovits (2005).

4 Brownlee (2012), ch. 8; and Brownlee (2008).
} 
Lefkowitz has answered in his article in this issue. Among other things, my reasons concern the meaning of claim rights; the dubiousness of penalizing civil disobedients in order to achieve either specific or general deterrence; and the inconsistency in saying that civil disobedience is a legitimate mode of political engagement but people still have symbolic reasons to accept a penalty for it. Here, I will not comment further on the nature of rights. Lefkowitz is correct to say that he and I conceive of rights differently. I will also not comment on using penalties as a deterrent except to note that deterrence is one of the main justifications offered for punishment, and as such it smudges the conceptual line between punishment and penalization on which Lefkowitz relies. This brings to light a further reason to reject penalization as a legitimate response to civil disobedience, which is its communicative blurriness.

Before I elaborate on communicative blurriness, let me comment briefly on Lefkowitz's rather romantic claim that penalizing civil disobedience is legitimate because by accepting penalties, civil disobedients

...symbolically recognize the costs their illegal conduct imposes on others, and perhaps more importantly, symbolically affirm the citizens' collective authority to settle reasonable disagreements over the design of morally necessary collection action schemes. ${ }^{5}$

For civil disobedients to make such symbolic gestures, they must act voluntarily. But, by definition, penalties are not voluntary. Penalties are not offered, but inflicted upon people. If disobedients do not pay a penalty imposed on them, they will be prosecuted. I have made a similar complaint about communicative theories of punishment which claim to be dialogic. We do not engage in a genuine dialogue with a convicted person when we tell her what her reparative actions will be. ${ }^{6}$ Similarly, we do not offer a person a meaningful way to symbolically affirm anything when we impose a penalty significant enough to constitute 'a genuine sacrifice' for her.

Now, Lefkowitz might concede that penalties are imposed, but claim that they are imposed here on willing subjects. Civil disobedients as civil disobedients willingly pay the penalties imposed on them because they are well-motivated, serious political participants, he might say.

The problem with that response is that we cannot distinguish between disobedients who wish to acknowledge symbolically the costs of their participating just outside the bounds of the law, and disobedients who are identical to them in all other ways, but who do not wish to acknowledge such costs and who pay the penalty only to avoid further burdens such as prosecution. Moreover, Lefkowitz leaves no room for the idea that the penalty set could be too high (even if it does not discourage all protest) and, hence, as such, could be a legitimate object of protest in itself, rather than acceptance.

\footnotetext{
5 Lefkowitz (2017), 5.

${ }^{6}$ See Brownlee (2011).
} 
One (romantic) solution would be to set up a scheme so that civil disobedients could come forward of their own accord to contribute money or personal services to the public good to acknowledge the costs associated with their disobedience.

Such a scheme would have the additional benefit of avoiding the communicative blurriness of penalization. Although many contemporary philosophers of criminal law follow Feinberg (1965) in distinguishing between punishing people (which communicates condemnation of their behaviour) and penalizing people (which does not), nevertheless judges, politicians, society, and civil disobedients may well find this distinction merely semantic. If a judge imposes a burden weighty enough to be a 'genuine sacrifice' (and not merely to cover the costs of any damage done), ${ }^{7}$ then, to all involved, that burden will look and feel like punishment. ${ }^{8}$

More importantly, unless we move civil disobedience cases out of the courtrooms, which would be hard to do, judges risk communicating blurry messages if they seek to penalize, but not punish, civil disobedients for their civil disobedience. Judges must pass judgment not only on the civil disobedience, but also on the vandalism, trespass, road block, whistleblowing, etc. Should judges impose a penalty for the civil disobedience (which is not presently an offence in any jurisdiction) and then a punishment for the ordinary offence? Is that double counting? If one civil disobedient damages property and another civil disobedient does not, should judges penalize them equally because they each engaged in civil disobedience? Should judges penalize a civil disobedient regardless of whether she causes damage or injury?

My own view on appropriate legal responses is that civil disobedients enjoy defeasible claim-right protection against all forms of state interference including penalisation and punishment. Since these rights are defeasible, judges may sometimes justifiably intrude upon these rights (i.e. infringe upon them) when these rights conflict with either other rights or significant goods. In my view, judges should apologise to civil disobedients if they must infringe upon their rights and punish them for their disobedience. Although such apologies might seem quirky, conflicts of rights are common, and apologizing for breaching rights in order to resolve such conflicts should be more common than it is. ${ }^{9}$

As this brief discussion indicates, Lefkowitz and I can find many points of intersection and complementarity in our views, but we also have some intractable disagreements about the nature, scope, and force of the right to civil disobedience. Our disagreements are not merely academic. They have implications for policymaking and judging. We may leave it to others to decide which account is more theoretically compelling and more palatable in its practical implications.

Acknowledgements I am grateful to Kartik Upadhyaya and Ben Saunders for valuable feedback on this piece. I thank Ben Saunders for his editorial work. Finally, I am grateful to David Lefkowitz for our ongoing conversation about civil disobedience.

\footnotetext{
7 William Smith and I have a brief exchange about this point in Smith (2016) and Brownlee (2016).

${ }^{8}$ In a previous defence of his view, Lefkowitz argues that the penalties for civil disobedience could include not only monetary fines but also temporary incarceration, which is a paradigmatic, contemporary method of punishment. See Lefkowitz (2007).

9 Brownlee (2012), chs. 7 and 8.
} 
Open Access This article is distributed under the terms of the Creative Commons Attribution 4.0 International License (http://creativecommons.org/licenses/by/4.0/), which permits unrestricted use, distribution, and reproduction in any medium, provided you give appropriate credit to the original author(s) and the source, provide a link to the Creative Commons license, and indicate if changes were made.

\section{References}

Brownlee, Kimberley. 2008. Penalizing Public Disobedience. Ethics 118: 711-716.

Brownlee, Kimberley. 2011. The Offender's Part in the Dialogue. In Crime, Punishment, \& Responsibility, ed. R. Cruft, M. Kramer, and M. Reiff, 54-67. Oxford: Oxford University Press.

Brownlee, Kimberley. 2012. Conscience and Conviction: The Case for Civil Disobedience. Oxford: Oxford University Press.

Brownlee, Kimberley. 2016. Reply to Critics. Criminal Law and Philosophy 10(4): 721-739.

Feinberg, Joel. 1965. The Expressive Function of Punishment. The Monist 49:3, Philosophy of Law, 397-423.

Lefkowitz, David. 2007. On a Moral Right to Civil Disobedience. Ethics 117: 202-233.

Lefkowitz, David. 2017. In Defence of Penalizing (but not Punishing) Civil Disobedience. Res Publica. https://doi.org/10.1007/s11158-017-9362-5.

Markovits, Daniel. 2005. Democratic Disobedience. Yale Law Journal 114: 1897-1952.

Raz, Joseph. 1979. The Authority of Law. Oxford: Oxford University Press.

Smith, William. 2016. The Burdens of Conviction: Brownlee on Civil Disobedience. Criminal Law and Philosophy 10(4): 693-706.

Tasioulas, John. 2012. Towards a Philosophy of Human Rights. Current Legal Problems 65: 1-30. 